Гибадуллин Р.М. Проблема социально-политической миссии улемов в российском исламоведческом дискурсе // Исламоведение. 2017. Т. 8. № 3. С. 20-34

\begin{tabular}{|c|c|c|}
\hline 倍 & $\begin{array}{c}\text { ИСЛАМ В РОССИИ } \\
\text { Ответственный за рубрику: Ю.М. Лысенко }\end{array}$ & $\begin{array}{l}\text { ISLAM IN RUSSIA } \\
\text { Person in charge of the section: } Y u . M \text {. } \\
\text { Lisenko }\end{array}$ \\
\hline (1) & С Исламоведение, 2017. Т. 8, № 3 (33) & $\begin{array}{l}\text { (C) Islamic Studies (Islamovedenie), } 2017 . \\
\text { Vol. 8, № } 3 \text { (33) }\end{array}$ \\
\hline
\end{tabular}

\title{
DOI: 10.21779/2077-8155-2017-8-3-20-34
}

УДК 297:322.2

P.М. Гибадуллин ${ }^{1}$

\section{Содержание статьи}

Введение

Проблема идеологизации политических аспектов религиозного лидерства в исламе

Социальный социально статус

улемов: гражданская

самоорганизация как исламский

идеал

Политическое кредо улемов в

мусульманском обществе

Заключение

\section{Информация о статье}

Поступила в редакцию: 22.04.2017. Передана на рецензию: 25.04.2017. Получена рецензия: 08.05.2017. Принята в номер: 25.08.2017.

\section{Проблема социально-политической миссии улемов в российском исламоведческом дискурсе}

Набережночелнинский институт (филиал) Казанского (Приволжского) федерального университета; nafisagi@gmail.com

Статья посвящена одной из актуальных проблем в изучении ислама - проблеме социально-политического предназначения мусульманских учёных - улемов. Автор предлагает рассматривать проблему не только через призму описания противоречивых реалий в социальной практике улемов, как это часто делается, но и с учётом существующего в исламской традиции идеала религиозного лидерства, который мусульмане стремятся воплотить в институте улемов. С этой позиции ставится вопрос о том, насколько постсоветская дискурсивная практика свободна от ориенталистского подхода, наделяющего улемов конформизмом перед лицом сильной власти и приверженностью тоталитарному идеалу. Автор предлагает свой подход, рассматривая улемов как гражданский институт уммы, выражающий исламский идеал самоорганизованной, автономной от власти, социально авторитетной и политически активной научной общественности. Такой подход утверждается сегодня во многом под влиянием научных достижений Запада. В этой связи автор делает вывод о том, что проблема идеологизации социально-политических аспектов религиозного лидерства улемов должна осмысливаться в контексте сложной диалектики взаимодействия западной либеральной, советской марксистской и националистических, в т. ч. имперской, традиций.

Ключевые слова: улемы, дискурс, исламоведение, ориентализм, европоцентризм.

\section{DOI: $10.21779 / 2077-8155-2017-8-3-20-34$}

\footnotetext{
${ }^{1}$ Рустам Марсельевич Гибадуллин - кандидат исторических наук, доцент кафедры социальногуманитарных наук, Набережночелнинский институт (филиал) Казанского (Приволжского) федерального университета, orcid.org/0000-0003-4273-3731
} 
UDC 297:322.2

R.M. Gibadullin ${ }^{2}$

\section{Content of the article}

Introduction.

The problem of indoctrination of social and political aspects of religious leadership in Islam. The social status of the ulama: citizens of Skye selforganization as the Islamic ideal. The political creed of the Ulema in the Muslim society.

Conclusion.

\section{Information about the article}

Received: 22.04.2017.

Submitted for review: 25.04.2017.

Review received: 08.05.2017.

Accepted for publication: 25.08.2017.

\title{
The Issue of the Socio-Political Mission of the Ulema in the Russian Islamic Discourse
}

\author{
Naberezhnye Chelny Institute (Branch) of the Kazan (Volga region) Federal University; \\ nafisagi@gmail.com
}

The article is devoted to one of the most relevant issues of Islamis studies - the problem of socio-political mission of Muslim scholars - the ulema. The author proposes to consider the problem not only through the prism of describing the contradictory realities in the social practice of the ulama, as is often done, but also taking into account the ideal of religious leadership existing in the Islamic tradition that Muslims seek to implement in the Ulema institute. This poses the question of how postSoviet discursive practice is free from the orientalist approach that empowers the ulema with conformism in the face of strong authorities and adherence to the totalitarian ideal. The author proposes a different approach that regards the ulema as a civil institution of the ummah, expressing the Islamic ideal of a self-organized, autonomous, socially authoritative and politically active academic community. This approach is asserted today largely under the influence of academic achievements of the West. In this connection, the author also concludes that the problem of ideologization of the sociopolitical aspects of the religious leadership of the ulama should be considered in the context of the complex dialectics of interaction between Western liberal, Soviet Marxist and nationalist, including imperial, traditions.

Keywords: the ulema, discourse, Islamic studies, orientalism, eurocentrism.

\section{Введение}

Одной из малоизученных сторон возрождения ислама в постсоветской России является то, как в ходе этого возрождения осмысливается и решается проблема религиозного лидерства, связанная с функционированием социального института мусульманских учёных - улемов. Наиболее сложный и к тому же часто идеологизируемый аспект проблемы составляет определение социально-политического предназначения улемов, их роли и места в контексте остро обсуждаемых сегодня в России взаимоотношений общества и власти. Для российских мусульман решение проблемы представляется чрезвычайно непростым делом, поскольку ислам в вопросах институализации деятельности улемов, их религиозного лидерства лишь устанавливает общие принципы, а не предписывает детализированную схему, которой надо жёстко

\footnotetext{
${ }^{2}$ Rustam Marsel'evich Gibadullin - Candidate of Sc. (History), Associate Professor of the Department of Social and Human Sciences, Naberezhnye Chelny Institute (Branch) of the Kazan (Volga region) Federal University, orcid.org/0000-0003-4273-3731
} 
Гибадуллин Р.М. Проблема социально-политической миссии улемов в российском исламоведческом дискурсе // Исламоведение. 2017. Т. 8. № 3. С. 20-34

следовать. Это предполагает творческий поиск некой оптимальной для российских мусульман модели, которая, однако, не должна выходить за рамки ислама. Выполнить последнее условие особенно сложно, учитывая, что на решение проблемы оказывают давление противоречивые факторы: существование российских мусульман в специфических условиях немусульманской страны и связанные с этим государственнические и секулярные традиции, а также разные группы интересов, имеющиеся как среди самих мусульман, так и в структурах государственной власти.

Значительное и совершенно особое влияние на решение проблемы улемов и в целом на религиозную ситуацию в России оказывает и исламоведение вкупе с другими науками, изучающими ислам, в которых наряду с академизмом заключён общественно и политически значимый дискурс. Этот дискурс, условно названный нами исламоведческим, выходит за рамки собственно исламоведения, особенно в классическом его понимании. Он формируется широким кругом научной и научнопопулярной литературы, причём представленной как отечественными, так и изданными в России зарубежными авторами. Исламоведческий дискурс следует рассматривать как своеобразный и важный индикатор отношений мусульман с их немусульманским окружением, устанавливающий потенциальные границы взаимопонимания. Немусульмане видят в исламоведческой литературе источник получения «объективной» информации об исламе и, в конечном счёте, основу для выработки критериев в решении проблем мусульман. Со своей стороны мусульмане, хотя и оценивают исламоведческий дискурс более критично, как секулярный и не вполне адекватный исламу, всё же находят в нём для себя определённые гарантии, поскольку он фиксирует максимально возможные пределы того, как немусульманское окружение готово понимать и признавать специфику ислама. Так, в отличие от часто исламофобских материалов СМИ, научно-справочные издания выражают апробированные в исламоведении, экспертные точки зрения, с которыми так или иначе вынуждены считаться официальные структуры, декларирующие необходимость учитывать в своих политических решениях интересы ислама.

Российский исламоведческий дискурс ещё не стал предметом серьёзных исследований. Поэтому трудно понять, в какой мере его можно рассматривать в духе теории ориентализма Эд. Саида как проявление колониалистской и европоцентристской идеологии, враждебной исламу. Сегодня не без влияния этой теории ведутся споры о том, насколько российское исламоведение подвержено государственному заказу, мешающему адекватно осмысливать проблемы ислама ${ }^{3}$. Так, идеология Советского государства приписывала исламу тоталитарный социальнополитический идеал, оправдывающий тиранию правителей и пассивность общества, что часто позволяло говорить об улемах как о выразителях соответствующего мировоззрения, характеризующихся конформизмом и полуэтатистскими формами самоорганизации. В сущности, именно такой взгляд на улемов, с которыми привычно ассоциируется «мусульманское духовенство», культивируется сегодня в России, в т. ч. на официальном уровне, едва ли не как исламская норма или, по крайней мере, как освящённая историей традиция российских мусульман. В действительности же исламское представление об улемах предполагает нечто совершенно противоположное. Во-первых, мусульманские учёные в социально-политическом измерении - это прежде всего автономная от государства, особым образом самоорганизованная, неформальная корпорация. Во-вторых, осуществление ими политического лидерства, помимо прочих

3 По мнению исследователей, именно государственнический менталитет, усиленный идеологемой «дружбы народов», объясняет, почему в России осознавать собственный ориентализм трудно и непривычно [1, с. 25], а в регионах - «ощущать своё колониальное прошлое <..> болезненно и неприятно» [11, с. 7-10]. 
функций, является для них не только возможным - благодаря их общественному авторитету и влиянию, но и желательным, а иногда и необходимым - в силу их исламского этоса, взывающего к политическому участию. В данной статье предлагается выяснить, в какой мере такое представление об улемах, их социальнополитическом кредо отражено в российском исламоведческом дискурсе. Другими словами, помогает ли он понять исламский взгляд на проблему возрождения института улемов в России, тем самым способствуя осознанию того, что проблема должна решаться прежде всего с позиций ислама и в его интересах.

\section{Проблема идеологизации социально-политических аспектов религиозного лидерства в исламе}

Согласно исламоведческой интерпретации, социальное лидерство в исламе имеет целью претворение в жизнь Божественного Откровения и обеспечивается улемами как носителями высшего авторитета, чья признанная обществом религиозная квалификация даёт им право интерпретировать Коран и Сунну, а также вырабатывать основанные на них знания и практические рекомендации, необходимые для функционирования и развития общества. Из этого вытекает важная цивилизационная особенность ислама, на которую указывает современный исследователь Н. Нурулла-Ходжаева: «Именно герменевтика - умение представлять божественное знание и применять его в жизни», являясь «приоритетным в [мусульманском] обществе», обусловила «выдвижение на первый план не субъектов власти, а тех, кто обладал знанием священных текстов и мог правильно их комментировать». Хотя данный феномен, как отмечает автор, «не столь часто обсуждается в среде современных экспертов религии» [14, с. 69]. Необходимо лишь уточнить, что в исламской традиции обладание религиозными знаниями (герменевтика, или экзегетика), считающееся главным источником легитимности социального лидерства, противопоставляется не столько власти как таковой, сколько секулярным основаниям её легитимации, будь то наследственный или выборный механизм, традиции или чья-то харизма, способность демонстрировать силу или добиваться экономической эффективности и т. д.

Несомненно, это означает, что исламское представление об улемах несёт на себе печать социальной концепции ислама. Поэтому, говоря о них, следует видеть не только противоречивые реалии в их социальной практике, как это часто делается, но и тот исламский идеал, который мусульмане стремятся воплотить в институте улемов. К сожалению, этот важный аспект часто упускается из виду российскими исламоведами. Например, в фундаментальном отечественном академическом издании «Ислам: энциклопедический словарь» (М.: Наука, 1991) понятие «улемы» раскрывается через описание изменчивой исторической практики его использования в исламском мире, но вне контекста формирования и отстаивания мусульманами идеала социального лидерства. Возможно, именно из-за подобной недооценки заключённых в понятии улемов ценностно-идеологических и социально-политических значений оно и вовсе отсутствует в некоторых словарях, причём даже в тех, которые претендуют на то, чтобы «разъяснить большинство основных понятий и терминов, используемых в исламской традиции» [2, с. 4]. В целом же в российских исламоведческих словарях интерпретация понятия «улемы» («улама»), означающего «общепризнанных авторитетных знатоков исламской теории и практики» [7, с. 221], или точнее, «теологии и религиозного права» [15, с. 261], не противоречит существующему в исламской традиции образу, хотя и не раскрывает его в полной мере.

В России проблематика социально-политической миссии улемов и в целом политических аспектов ислама отягощена грузом идеологических ограничений прошлого и настоящего. В советское время она могла рассматриваться лишь под 
определённым углом зрения и применительно лишь к мусульманскому зарубежью, но не к России. Последнее объясняется тем, что советское государство в своей внутренней и внешней политике использовало разные образы ислама. Так, в соответствии с проводившимся в стране антирелигиозным курсом официальная трактовка отечественной истории, построенная на формационных схемах классовой борьбы, предписывала религии «реакционную» роль. Её сводили к попыткам религиозных деятелей предотвратить революционный протест социальных «низов» с помощью внушения им идеи безусловной покорности «верхам» и смирения перед любыми формами социальной несправедливости. Исходя из этого, например, утверждалось, что «мусульманские лидеры всегда защищали политические и экономические интересы эксплуататоров» $[6$, с. 730$]$. Чаще же всего тему ислама в российской истории просто замалчивали, ограничиваясь констатацией его «реакционности».

Иной подход к исламу диктовала идеологическая политика СССР в отношении мусульманских стран [13, с. 99]. Она должна была опираться на более или менее адекватные представления об исламе, его социальной концепции. Это обеспечивалось реальными научными исследованиями прежде всего в области академического исламоведения, которое было относительно свободно от наиболее вульгарных антирелигиозных установок, поскольку было связано с досоветскими и зарубежными научными традициями в изучении классического, средневекового ислама. Подход к изучению мусульманского мира Нового времени был, однако, более политизированным. В нём сохранялось характерное для первых лет Советской власти стремление выявить в исламе «революционное» содержание и «прогрессивные» черты, особенно его социально-освободительный, антиколониальный потенциал. Интересно, что попытка перенести этот «внешнеполитический» подход на историю российских мусульман была предпринята этнорегиональными историками в рамках течения «мирасизма» (конец 1950-1980-е гг.), отстаивавшего тезис о мусульманском «Просвещении» в России [6, с. 737-738]. Однако предложенный «мирасистами» образ мусульманских «просветителей», выражавших антирелигиозный по своей сути социальный протест, отнюдь не реабилитировал ислам, a, напротив, противопоставлялся его «реакционной» сущности. Невозможно было также по аналогии с историями стран третьего мира говорить об активной роли ислама в национально-освободительном движении мусульманских народов России, поскольку антиколониальная проблематика, свойственная ранней советской историографии (М. Покровский), была исключена из сферы отечественной истории, более того, завоевание Российской империей мусульманских регионов (Поволжья, Северного Кавказа, Средней Азии) было объявлено «исторически прогрессивным» [6, с. 730]. Этот идеологически обусловленный разрыв в подходах к отечественной и зарубежной проблематике ислама с некоторыми изменениями сохраняется и в постсоветское время.

Предлагаемые сегодня подходы также не свободны от идеологизации. Негативная инерция советской эпохи явно проявляется в том, что постсоветский государственный заказ, хотя и не так жёстко, как раньше, но всё же предписывает российскому мусульманству в вопросах подготовки улемов ограничивать свои связи со странами исламского мира. По этой же причине проблему возрождения института улемов в России стараются не связывать с общеисламскими канонами религиозного лидерства или изучением зарубежного опыта, а, напротив, как будто стремятся оградить от них решение проблемы, сводя её к реанимации отечественной дореволюционной модели, которая некритично идеализируется на фоне советской эпохи «воинствующего атеизма». Возможно, этому способствовало то, что на волне постсоветского переосмысления прошлого в центре внимания мусульманской общественности оказались последствия советской антирелигиозной политики, особенно 
разрушительные в конце 1920-1930-е гг., когда в результате массовых репрессий «мусульманское духовенство утратило наиболее активную и образованную часть религиозных деятелей» [10, с. 78].

Это заслонило собой на некоторое время негативные стороны существования мусульман в Российской империи, связанные с исходившими от неё угрозами если не уничтожения, то деформации ислама. Как известно, одной их них стала навязанная российским мусульманам модель религиозного лидерства, которая воспринималась ими как аналогичная учреждениям в православной церкви, и поэтому не вполне легитимная с исламской точки зрения. Тем не менее, видные исламоведы предпочитают говорить «о "российском рецепте" взаимоотношения светской власти и исламских институтов», подчёркивая, что «механизм духовных управлений», созданный Екатериной II, и связанные с ними политико-правовые решения и прецеденты «составляют бесценный опыт, завещанный нам имперской Россией» [16, с. 45]. Такой подход получил сегодня широкое распространение благодаря тому, что он соответствует набирающим силу националистическим трендам. С одной стороны, русскому имперскому сознанию, реставрирующему величественный образ собственного досоветского прошлого, а с другой - стремлению «мусульманских» регионов обосновать свою культурно-религиозную самобытность идеями о «российском» или, например, «татарском» исламе.

Постсоветский государственный заказ не только поощряет приукрашивание состояния ислама в Российской империи, включая организационные модели и практики «мусульманского духовенства», но и предписывает ему сегодня в качестве традиции, идущей от этого прошлого, характерную государственническую позицию. Так, выступление В. Путина на состоявшейся в октябре 2013 г. в Уфе встрече с муфтиями духовных управлений России хорошо раскрывает суть государственного подхода к определению их политико-идеологического предназначения. Президент напрямую связал его с идеей безопасности страны, поставив перед «мусульманским духовенством» задачу «служить обществу и своему государству, <.. > защищая его как от внешних врагов, так и от любых проявлений экстремизма». К деструктивным «политическим силам» были отнесены «неформальные лидеры», которые, «являясь представителями, как правило, чуждых нашей стране богословских школ, <..> стремятся к подрыву единства российского общества и развалу $<\ldots>$ страны». Исходя из этого, было предложено создать «собственную исламскую богословскую школу», с позиций которой можно было бы «откликаться на самые актуальные события и в России, и в мире», давать «оценки, которые будут понятными и авторитетными для верующих» ${ }^{4}$.

Очевидно, как прямой отклик на это следует понимать заявление ведущих исламоведов о том, что «развитие академического исламоведения в России имеет важное государственное значение, особенно в свете стоящей перед исламской общиной страны задачи воссоздания отечественной богословской школы» (А. Аликберов) [3, c. 71-72]. Причём вопрос даже ставится в практическую плоскость разработки «образовательных программ, которые могли бы стать базисом» для подготовки «мусульманского духовенства» и которые своими «особыми подходами» и «особыми темами» (например, «Ислам в России») могли бы быть «интересны даже выпускнику ал-Азхара» (М. Пиотровский) [16, с. 47]. Такие претенциозные задачи заставляют российских исламоведов утверждать, что они, в отличие от своих зарубежных коллег,

\footnotetext{
${ }^{4}$ См.: Начало встречи с муфтиями духовных управлений мусульман России 22 октября 2013 г. // [Электронный pecypc]. URL: http://www.kremlin.ru/events/president/transcripts/19474 (дата обращения: 28.05.2016).
} 
свободны от ориентализма 5 . Так, по мнению А. Аликберова, «европоцентризм в некоторой форме отчасти имел место и в истории России», но «классическое востоковедение, по крайней мере в лице выдающихся представителей Петербургской школы, придерживалось сбалансированных подходов» [3, с. 57-58]. По сути, ту же мысль отстаивает М. Пиотровский, когда говорит о том, что «в российском востоковедении ещё с дореволюционного времени» наряду с его откровенно идеологизированными направлениями - «политическим востоковедением, обеспечивавшим политические (чаще всего - внешнеполитические) задачи России», и «миссионерским, обеспечивавшим интересы православной и прочей государственной идеологии», всегда существовало не подверженное идеологизации «академическое» направление, «призванное умножать знания и смыслы» [16, с. 47].

Однако даже самый оптимистичный взгляд на академическое востоковедение как на некий островок, существующий вне политики, не избавляет его от ситуации, когда оно по тем или иным вопросам вынуждено либо принимать идеологический заказ государства, либо вступать с ним в противоречие. По крайней мере, такая ситуация сложилась в постсоветский период в связи с тем, что академические представления об улемах как исламском институте, определяющем их социальный статус и социальнополитические аспекты их лидерства, стали более полными и свободными от прежних стереотипов. В значительной мере этому способствовали изданные в России работы зарубежных авторов, в том числе посвящённые истории российских мусульман ${ }^{6}$. Именно эти работы подводят к тому, чтобы проблематику улемов начинать рассматривать с учётом отстаивания мусульманами исламского идеала, определяющего, что такое мусульманский учёный в социально-политическом измерении, прежде всего относительно государства и общества: является ли он частью и выражением властной системы или же самостоятельной по отношению к ней инстанцией гражданского общества.

\section{Социальный статус улемов:}

\section{гражданская самоорганизация как исламский идеал}

Прежде всего следует отметить важность зафиксированного в исламоведческих словарях представления о неформальном статусе улемов. Отсутствие в исламе официальной организации, аналогичной христианской церкви, изначально придало неформальный характер религиозным объединениям мусульман и их лидерам. Социальный институт религиозного лидерства, представленный улемами, не имеет под собой какой-либо строго канонизированной организационной модели, зафиксированной в исламском праве. В его основе лежит, в конечном счёте, общественное признание религиозного авторитета в соответствии с исторически сложившимися критериями, важнейшими из которых являются религиозное знание и личное благочестие мусульманина. Это способствовало тому, чтобы понятие «улемы» стало «собирательным названием», используемым мусульманами для обозначения «как теоретиков, так и практических деятелей в области <..> образования, судопроизводства на основе шариата и исполнения обрядов» [18, с. 239-240]. Такое расширенное понимание формировалось в исламском мире исторически, по мере того, как общественный престиж улемов долгое время только возрастал и, становясь всё более притягательным, даже оспаривался различными группами: и «представителями

\footnotetext{
5 Это учитывает позицию российских мусульман, которая допускает привлечение к подготовке улемов лишь «положительно относящихся к исламу» светских учёных [17, с. 33].

${ }_{6}^{6}$ В. Бобровников отмечает, что в отличие от отечественных историков применить теорию ориентализма к истории российских мусульман пока смогли лишь зарубежные «историкирусисты и занимающиеся мусульманскими окраинами России исламоведы» [5, с. 75].
} 
разных отраслей знания (мухаддисами, факихами, мутакаллимами и т. д.)», и «исполнителями религиозно-общественных функций (кади, муфтиями, имамами, хатибами, мударрисами и т. д.)» $[18$, с. 240; 7, с. 221]. Улемы нередко могли иметь и светские профессии, при этом оставаясь авторитетными духовными наставниками или советниками по религиозным вопросам [15, с. 262].

Конечно же, в реальности религиозная практика мусульман далеко не всегда строилась на неформальном лидерстве улемов. Этот общественный идеал приходилось отстаивать прежде всего перед лицом постоянно проявлявшегося стремления власти установить собственную монополию в вопросах религии. На протяжении всей своей истории исламский мир сталкивался со стремлением властей к огосударствлению исламских институтов религиозного лидерства, что всегда вызывало сопротивление общества. По свидетельству М. Ходжсона, уже в средневековый период социальный протест вызывали «официальные суннитские улемы, которые нашли компромисс с эмирами и получили от них <..> назначения» [19, с. 693]. В фольклоре они были неизменным объектом насмешек, при этом воспевался образ учёного, добровольно отказавшегося от предложенной ему выгодной должности. Мусульманские правители так и не смогли добиться полного контроля над улемами. Ту или иную самостоятельность сохраняли даже те из них, в чьих руках находились функции шариатского суда: хотя «мусульманского судью, кади и подчинявшихся ему служителей шариата должен был назначать эмир, но, как правило, они избирались из узкого круга лиц, признанных во всём городе, и могли иногда действовать без вмешательства эмира» $[19$, с. 422]. В конечном же счёте их относительная независимость от властей базировалась на автономии шариатского права, сохранявшейся во всех средневековых мусульманских империях [19, с. 694] и способствовавшей развитию «уникального исламского типа города, отличного от всех предыдущих» [19, с. 421]. В соответствии с исламским «космополитическим мировоззрением» житель такого города не ограничивал свой статус «правами и обязанностями местного городского масштаба», а «как свободный мусульманин <...> являлся гражданином всего Дар-аль-ислама» и определял свои обязанности «только тем, что ждёт от него всевидящий Бог» [19, с. 421]. Именно поэтому улемы могли опираться на признание и материальную поддержку не только эмиров, но и обычных горожан [19, с. 422].

Отметим, что зарубежные авторы изданных у нас работ по истории исламского мира (М. Ходжсон, К. Армстронг, Б. Люис и др.) гораздо чаще и основательнее, чем это принято в России, исследуют демократические, антиэтатистские традиции религиозного лидерства в исламе, имеющие глубокие основания в его социальной концепции. Это проявляется и в изучении истории улемов в России, чему яркий пример даёт монография М. Кемпера, посвящённая улемам Волго-Уральского региона в конце XVIII-XIX вв. Автор отмечает типичность для всего мусульманского мира той ситуации, которая сложилась в регионе, где имперские власти с помощью созданной ими официальной религиозной структуры старались свести к минимуму любую не подконтрольную им деятельность улемов и их общественное влияние. Эта структура «Духовное собрание» во главе с муфтием - была организована по аналогии с подобными структурами в странах исламского мира (Османской империи и Бухарском эмирате) и, несмотря на свой гораздо меньший масштаб, выполняла схожие функции: легитимировала в глазах мусульман верховную власть и контролировала деятельность мечетей, школ и судов [9, с. 71-72].

В этой связи стоит напомнить, что сегодня представление о Духовном собрании как неком общепринятом в исламском мире и едва ли не канонизированном институте играет важную идеологическую роль в обосновании легитимности современных 
преемников Собрания - муфтиятов. Возможно, поэтому российские историки не склонны увлекаться исследованием исторических фактов и процессов, способных поколебать такую легитимность. Между тем именно таким фактам и процессам Кемпер уделяет в своей работе значительное место, показывая, сколь малоубедительными в глазах улемов выглядели претензии Собрания и муфтия на религиозное лидерство в регионе и сколь «сильно было стремление учёных освободиться из-под влияния центрального муфтията в Уфе» [9, с. 71-72], т. е. Духовного собрания.

Из работы Кемпера видно, что оппозиция улемов Духовному собранию, несомненно, носила глубоко системный характер. Во-первых, она имела под собой достаточно широкую социальную базу в виде финансово независимых мусульманских общин, в которых имамы (муллы), считавшиеся улемами, пользовались большим авторитетом и поддержкой [9, с. 76-78]. Во-вторых, что более существенно, оппозиция опиралась на соответствующие исламские идеологические традиции. В частности, Кемпер указывает на учение аль-Биргиви (XVIв.), на котором основывалась развернувшаяся в XVII в. в Османской империи общественная критика улемов на государственной службе. Оно получило распространение среди улемов Волго-Уралья в XIX в. [9, с. 231], особенно среди тех, чья оппозиционность официальному духовенству основывалась на идеалах аскетического благочестия [9, с. 620]. Профессиональный и корпоративный этос таких улемов выражали многочисленные цитаты, более ранних классиков мусульманской теологии, приводимые ими в своих трудах, например, в духе формулы матуридитского автора XII в.: «Похвалы заслуживают те улемы, которые $<\ldots>$ держатся в стороне от испорченности, богатых (байлар) и от властителей (солтаннар)» [9, с. 166]. Несомненно, среди подобных цитат особенно авторитетными в глазах поволжских мусульман-ханафитов должны были выглядеть ссылки на высказывания Абу-Ханифы, который, в частности, предостерегал «от контактов с султаном, так как последние могли бы привести <...> в ад» [9, с. 201].

Важным уточнением Кемпера является то, что мусульманская оппозиция Духовному собранию не сводилась к его полному отторжению. Многие улемы, видя в нём «русское учреждение, а не духовное представительство мусульман» и не считая его поэтому легитимным, всё же признавали его практическую необходимость «в качестве связующего звена, посредника между русским правительством или губернскими властями и учёным миром» [9, с. 127]. Хотя ситуация вокруг Собрания порождала как надежды, так и разочарования. Так, удручало, что муфтии назначались властями, исходя лишь из их политической лояльности, но без учёта их религиозной квалификации, образования и общественного престижа [9, с. 491], и деятельность таких муфтиев могла принимать вопиющие формы и даже противоречить интересам мусульман. В то же время способность улемов открыто и иногда успешно этому противостоять становилась поводом для оптимизма, как, например, в случае с первым муфтием, против которого выступили некоторые кадии с обвинением его в коррупции и доведением дела до слушания в суде [9, с. 94]. Характерно, что именно в результате борьбы с этим муфтием на его должности, в конечном счёте, смог утвердиться представитель «оппозиционных» улемов, который, правда, по мнению Кемпера, так и остался единственным за всю историю Собрания муфтием, соответствовавшим по своим интеллектуальным и моральным качествам этому званию [9, с. 125]. Таким образом, оппозиционность провластным структурам совсем не обязательно означала полное отрицание их, неподчинение им или самоустранение от них. Иногда оппозиционеры даже боролись за вакансии в этих структурах, очевидно, в надежде использовать их возможности в интересах общины.

И всё же следует подчеркнуть, что более важным для улемов является отстаивание собственной модели социальной самоорганизации. В идеале она, по- 
видимому, должна означать не что иное, как научно-образовательную корпорацию, которая группируется вокруг исламских университетов, обладающих реальной автономией благодаря наличию у них вакуфного имущества. По сути, такую социальную самоорганизацию мусульманских учёных следует рассматривать как один из институтов гражданского общества. Возможно, о наметившемся сегодня стремлении российских мусульман к возрождению такого идеала свидетельствует то, что издание монографии Кемпера, в которой, как мы убедились, этот идеал имплицитно присутствует, было осуществлено усилиями мусульманского учебного заведения Российским исламским университетом (Казань).

\section{Политическое кредо улемов в мусульманском обществе}

Одним из ключевых моментов в характеристике идейного кредо мусульманского учёного является вопрос о том, какой должна быть его социальная ответственность и политическая миссия в исламском обществе. Этот вопрос всегда был крайне идеологизирован, особенно в России, где конформизм официальных мусульманских структур, жёстко предписанный им государством, приходилось обосновывать некорректным с исламской точки зрения тезисом о необходимости исключать социально-политическое из сферы религиозного. Между тем в исламоведческих работах нашло своё отражение совершенно иное понимание религиозности в исламе, основанное на признании её социально-преобразовательной направленности. Теологической посылкой к такому пониманию считается фундаментальный в исламе принцип единобожия («таухид»), который утверждает единство божественного мироздания и соответственно делает понятие исламской религиозности всеобъемлющим, а не противоположным светскому. Исходя из этого, на протяжении всей истории ислама совершенствование организации земной жизни всегда объявлялось сферой религиозного поиска, а стремление к утверждению социальной справедливости - божественным предписанием для каждого мусульманина (К. Армстронг) [4, с. 216]. По мнению исламоведов, именно религиозная освящённость политического мировоззрения мусульман позволяет теологам исламского мира призывать общество к политической активности. В частности, как показывает Н. Жданов, такой подход положен в основу идеологической концепции, сформулированной в программных документах Организации Исламская Конференция [8, c. 23].

В таком социально-религиозном измерении улемы, в силу своих идеологически значимых функций, должны были восприниматься и, действительно, всегда воспринимались как особая «активная и влиятельная социальная прослойка» исламского общества, занимающая в нём ключевые, лидерские позиции, в том числе в его политической жизни. Независимо от того, применяли улемы свою квалификацию «на службе у правителей или общины» [15, с. 262], «возглавляли городские общины, оппозиционные по отношению к властям или проправительственные» $[18$, с. 240], их идейным кредо считалось служение богу, точнее, его повелениям относительно рода человеческого, воплощённым в образе уммы как общества, основанного на шариатских идеалах единства и справедливости, равенства и братства. Именно поэтому образ уммы должен иметь приоритет в глазах улемов, что, по мнению С. Мусхаджиева, получило выражение в созданной ими политико-правовой доктрине ислама, согласно которой «мусульманское государство полностью строилось на основе “поручения", данного Богом умме», а не правителям, поэтому именно «община являлась неким его “консолидированным заместителем" в управлении деятельностью государства, действующим исключительно в рамках шариата» [12, с. 5]. 
Гибадуллин Р.М. Проблема социально-политической миссии улемов в российском исламоведческом дискурсе // Исламоведение. 2017. Т. 8. № 3. С. 20-34

Таким образом, ислам не просто обязывает улемов заниматься социальной и политической проблематикой, но и предписывает определённый этос в отношениях с правящей властью - критичный взгляд и внутреннюю готовность воздействовать на неё через сотрудничество или противостояние с ней вплоть до радикальных форм социального протеста. Однако в России исследователям всегда было непросто определить, насколько важное место в политической теории и мировоззрении улемов занимала идея социального протеста, или восстания, поскольку вопрос считался и продолжает считаться идеологически крамольным. На то есть разные причины. Это и стереотипы советского времени, когда в интересах борьбы с религией не допускалось, чтобы «реакционные муллы» играли «революционную» роль в истории. Это и идеологические установки постсоветских националистов-государственников, возрождающих сегодня приукрашенный образ Российской империи и откровенно замалчивающих её противоречия со своими мусульманскими подданными. Причём такой подход разделяет и современное мусульманское духовенство, которое явно во избежание опасных ассоциаций с темой исламского экстремизма старается не напоминать о восстаниях мусульман в прошлом, поддерживая их «верноподданнический» образ в российской истории.

Тем не менее, постсоветские исследователи всё чаще обращаются к теме протестных выступлений мусульман Российской империи. При этом о теологическом обосновании улемами своего участия в таких выступлениях гораздо более откровенно говорится в изданных у нас работах зарубежных авторов. По словам Кемпера, выступления в Волго-Уралье, «по крайней мере, их часть <...> была организована и возглавлена мусульманскими учёными», как это имело место, например, в восстании под руководством муллы Батыршы в середине XVIII в. [9, с. 57]. Более того, отмечены поразительные случаи, в частности, когда известный улем в звании ахунда, казалось бы, пользовавшийся доверием и поддержкой имперских властей, привлекавшийся ими к посольской службе и имевший земельные пожалования и награды, открыто призвал мусульманских подданных Российской империи к участию в восстании Пугачёва [9, c. 69]. Чрезвычайно важно то, что такой политический выбор улемов подкреплялся соответствующим теологическим обоснованием. В комментариях местных авторов к трудам средневековых классиков исламской теологии присутствовали характерные постулаты: «если мусульманин любит тиранов, то вера его ущербна» [9, с. 201]; если «султан (или муфтий, или кадий) выступает против шари'а, тогда его подчинённые вправе подняться против него» $[9$, с. 164] и т. д.

Для сравнения стоит обратить внимание на то, как сегодня официальные лидеры мусульман в регионе, имеющие статус улемов, рассматривают проблему своего участия в политике. Данный вопрос поднимается в книге В. Якупова «Ислам в Татарстане в 1990-е годы» (2005) [20], автор которой является членом Совета улемов и одним из высших должностных лиц в Духовном управлении мусульман РТ. Позиция автора выглядит несколько двойственной и противоречивой. Когда он говорит об аполитичности официальных религиозных лидеров мусульман Татарстана, трудно понять, что он имеет в виду: принцип, который разделяет сам, или же данность, которую описывает. Так, В. Якупов разъясняет, что в утверждениях «официального духовенства» о необходимости для мусульман «строить свою жизнь в соответствии с традициями и общественными принципами ислама» речь идёт «о приверженности исламским культурным ценностям, а не предписаниям, касающимся государственного устройства» [20, с. 10]. В то же время он признаёт социально-политическую сферу объектом религиозных устремлений мусульман, хотя и рассуждает об этом не с позиции ислама, а с точки зрения религии вообще: «у каждой религии есть свой идеал обустройства земной жизни, представления о предпочтительном государственном 
устройстве, функционировании человеческого сообщества, взаимоотношениях общества и индивида, гражданина и государства, <..> которые зачастую <..> становятся чуть ли не частью веры» [20, с. 14]. В соответствии с этим выражается даже надежда на то, что со стороны представителей мусульманского духовенства «в будущем можно ожидать попытки формирования ими политической ориентации целых общин и потенциального участия в решении политических вопросов» [20, с. 99].

\section{Заключение}

Полученные выводы позволяют внести некоторые важные, на наш взгляд, уточнения в продолжающийся сегодня в России разговор о том, насколько ей свойствен и свойствен ли в принципе ориентализм в изучении ислама. Несколько неожиданную картину даёт анализ постсоветской дискурсивной практики в интерпретации социально-политических аспектов религиозного лидерства в исламе. Во-первых, мы видим подход, который проявляется вопреки установкам государства, исключающим какую-либо самостоятельную социально-политическую активность улемов. В исламоведческих работах всё чаще говорится об исторической и теологической обоснованности в мире ислама иной модели религиозного лидерства улемов, рассматривающей их как один из гражданских институтов уммы - как особым образом самоорганизованную, автономную от структур государственной власти, социально авторитетную и политически активную часть научного сообщества. Для некоторых представителей «мусульманского духовенства» такой подход, очевидно, даёт надежду на то, что он может идеологически легитимировать в глазах государства их стремление к участию в политике, которое они не смеют открыто выражать, опасаясь обвинений в исламском экстремизме. Во-вторых, некая парадоксальность проявляется в том, что такой подход формируется сегодня в России во многом под влиянием научных достижений либерального Запада, который, казалось бы, считается источником ориенталистских представлений о тоталитарной социально-политической природе ислама. Возможно, это позитивное зарубежное влияние является продолжением советологического подхода, нацеленного в своё время на стимулирование исламской оппозиции советскому режиму. Так или иначе, ясно, что постсоветский дискурс в интерпретации социально-политической проблематики ислама следует осмысливать в контексте сложной диалектики взаимодействия западной либеральной, советской марксистской и националистических, в том числе имперской, традиций.

\section{Литература}

1. Алаев Л.Б. Ориенталистика и ориентализм. Почему книга Эдварда Саида не имела успеха в России? // Ориентализм vs ориенталистика: сб. статей / отв. ред. и сост. В.О. Бобровников, С.Дж. Мири. - М.: ООО «Садра», 2016. - С. 16-26.

2. Али-заде A.A. Исламский энциклопедический словарь. - М.: Издательский дом «Ансар», 2007. - 400 c.

3. Аликберов А.К. Российское исламоведение, его предмет и место в системе гуманитарных знаний (по следам одной научной дискуссии) // Ars Islamica: в честь Станислава Михайловича Прозорова / сост. и отв. ред. М.Б. Пиотровский, А.К. Аликберов; Ин-т востоковедения РАН. - М.: Наука - Вост. лит., 2016. - С. 51-76.

4. Армстронг K. Ислам: краткая история от начала до наших дней / пер. с анг. М. Беловой. - М.: Эксмо, 2011. - 320 с.

5. Бобровников В.О. Ориентализм - не догма, а руководство к действию? О переводах и понимании книги Э.В. Саида в России // Ориентализм vs ориенталистика: сб. статей / отв. ред. и сост. В.О. Бобровников, С.Дж. Мири. - М.: ООО «Садра», 2016. - С. 53-77. 
Гибадуллин Р.М. Проблема социально-политической миссии улемов в российском исламоведческом дискурсе // Исламоведение. 2017. Т. 8. № 3. С. 20-34

6. Бустанов А., Кемпер М. Мирасизм в татарской среде: трансформация исламского наследия в татарское просветительство // Ars Islamica: в честь Станислава Михайловича Прозорова / сост. и отв. ред. М.Б. Пиотровский, А.К. Аликберов; Ин-т востоковедения РАН. - М.: Наука - Вост. лит., 2016. - С. 729-745.

7. Гогиберидзе Г.М. Исламский толковый словарь. - Ростов н/Д: Феникс, 2009. $266 \mathrm{c}$.

8. Жданов Н.В. Исламская концепция миропорядка. - М.: Межд. отношения, 2003. $-568 \mathrm{c}$.

9. Кемпер M. Суфии и учёные в Татарстане и Башкортостане. Исламский дискурс под русским господством: пер. с нем. - Казань: Российский исламский университет, 2008. -675 c.

10. Минуллин И.Р. Мусульманское духовенство Татарстана в условиях политических репрессий 1920-1930-х гг. - Н. Новгород: ИД «Медина», 2007. - 87 с.

11. Мири С.Дж., Бобровников В.О. Введение // Ориентализм vs. ориенталистика: сб. статей / отв. ред. и сост. В.О. Бобровников, С.Дж. Мири. - М.: ООО «Садра», 2016. - С. 7-15.

12. Мусхаджиев С.X. Политико-правовая доктрина ислама: теоретический аспект // Вестник Майкопского государственного технологического университета. 2011. - Вып. 2. - С. 1-7.

13. Мухаметшин P.M. Исламоведение в Татарстане // Ars Islamica: в честь Станислава Михайловича Прозорова / сост. и отв. ред. М.Б. Пиотровский, А.К. Аликберов; Ин-т востоковедения РАН. - М.: Наука - Вост. лит., 2016. - С. 96-104.

14. Нурулла-Ходжаева Н.Т. Община в мусульманской традиции Центральной Азии // Вестник МГУКИ. - 2012. - № 4 (48) июль-август. - С. 67-71.

15. Ньюби Г. Краткая энциклопедия ислама: пер. с анг. - М.: ФАИР ПРЕСС, 2007. -384 c.

16. Пиотровский М.Б. О некоторых принципах преподавания истории и культуры ислама в России // Ars Islamica: в честь Станислава Михайловича Прозорова / сост. и отв. ред. М.Б. Пиотровский, А.К. Аликберов; Ин-т востоковедения РАН. - М.: Наука - Вост. лит., 2016. - С. 43-50.

17. Садур В. Тюрки, татары, мусульмане (статьи, очерки, эссе) / сост. и отв. ред. И.З. Мухамеджанов. - М.: Изд. дом «Марждани», 2012. - 400 с.

18. Халидов А.Б. Улама // Ислам: энциклопедический словарь. - М.: Наука. Главная редакция восточной литературы, 1991. - С. 239-240.

19. Ходжсон М. История ислама: Исламская цивилизация от рождения до наших дней / пер. с анг. А.Н. Гордиенко, И.В. Матвеева, Н.В. Шевченко; под науч. ред.Т.К. Ибрагима. - М.: Эксмо, 2013. - 1088 с.

20. Якупов В. Ислам в Татарстане в 1990-е годы. - Казань: Иман, 2005. $144 \mathrm{c}$.

\section{References}

1. Alayev L.B. Oriyentalistika i oriyentalizm. Pochemu kniga Edvarda Saida ne imela uspekha v Rossii? [Oriental Studies and Orientalism. Why did the Book of Edward Said Meet with No Success in Russia?] Oriyentalizm vs. oriyentalistika: Sb. Statey [Orientalism vs. Oriental Studies: a collection of articles] / otv. red. i sost. V.O. Bobrovnikov, S.Dzh. Miri. Moscow: Sadra, 2016. - S. 16-26 (In Russian)

2. Ali-zade A.A. Islamskiy entsiklopedicheskiy slovar. [Islamic encyclopedia] Moscow: Izdatelskiy dom «Ansar», 2007. - 400 s. (In Russian)

3. Alikberov A.K. Rossiyskoye islamovedeniye. ego predmet $\mathrm{i}$ mesto $\mathrm{v}$ sisteme gumanitarnykh znaniy. (Po sledam odnoy nauchnoy diskussii). [Russian Islamic Studies: the 
Subject and Place in the System of Humanitarian Knowledge. (In the Wake of One Academic Discussion)] Ars Islamica: $v$ chest Stanislava Mikhaylovicha Prozorova [Ars Islamica: in honor of Stanislav Mikhailovich Prozorov] / sost. i otv. red. M.B. Piotrovskiy, A.K. Alikberov; In-t vostokovedeniya RAN. - Moscow: Nauka - Vost. lit., 2016. - S. 51-76 (In Russian).

4. Armstrong K. Islam: kratkaya istoriya ot nachala do nashikh dney [Islam: Brief History from the Origins to the Present]; [per. s ang. M. Belovoy]. - Moscow: Eksmo, 2011.320 s. (In Russian)

5. Bobrovnikov V.O. Oriyentalizm - ne dogma, a rukovodstvo $\mathrm{k}$ deystviyu? $\mathrm{O}$ perevodakh i ponimanii knigi E.V. Saida v Rossii. [Orientalism: a Dogma or Guidelines for Action? On the Translations and Understanding of the Book by E.W. Said in Russia] Oriyentalizm vs. oriyentalistika: Sb. statey [Orientalism vs. Oriental Studies: a collection of articles] / otv. red. i sost. V.O. Bobrovnikov, S.Dzh. Miri. - Moscow: Sadra, 2016. - S. 53-77 (In Russian)

6. Bustanov A., Kemper M. Mirasizm v tatarskoy srede: transformatsiya islamskogo naslediya $\mathrm{v}$ tatarskoye prosvetitelstvo. [Mirasism among Tatars: the Transformation of Islamic Heritage into Tatar Enlightenment] Ars Islamica: $v$ chest Stanislava Mikhaylovicha Prozorova [Ars Islamica: in honor of Stanislav Mikhailovich Prozorov] / sost. i otv. red. M.B. Piotrovskiy, A.K. Alikberov; In-t vostokovedeniya RAN. - Moscow: Nauka - Vost. lit., 2016. - S. 729-745 (In Russian)

7. Gogiberidze G.M. Islamskiy tolkovyy slovar [Islamic Dictionary]. - Rostov n/D: Feniks, 2009. - 266 s. (In Russian)

8. Zhdanov N.V. Islamskaya kontseptsiya miroporyadka [Islamic Concept of World Order]. - Moscow: Mezhdunar. Otnosheniya, 2003. - 568 s. (In Russian)

9. Kemper M. Sufii $i$ Uchenyye v Tatarstane i Bashkortostane. Islamskiy diskurs pod russkim gospodstvom [Sufis and Scholars in Tatarstan and Bashkortostan. Islamic discourse under Russian Domination]; [per. s nem.]. - Kazan: Rossiyskiy islamskiy universitet, 2008. 675 s. (In Russian)

10. Minullin I.R. Musulmanskoye dukhovenstvo Tatarstana v usloviyakh politicheskikh repressiy 1920-1930-kh gg. [The Muslim Clergy of Tatarstan in the Face of Political Repression in the 1920-1930s] - N. Novgorod: Medina, 2007. - 87 s. (In Russian)

11. Miri S.Dzh., Bobrovnikov V.O. Vvedeniye. [Introduction] Oriyentalizm vs. oriyentalistika [Orientalism vs. Oriental Studies: a collection of articles]: Sb. statey / otv. red. i sost. V.O. Bobrovnikov, S.Dzh. Miri. - M.: Sadra, 2016. - S. 7-15 (In Russian)

12. Muskhadzhiyev S.Kh. Politiko-pravovaya doktrina islama: teoreticheskiy aspect [The Legal-Political Doctrine of Islam: Theoretical Aspect] Vestnik Maykopskogo gosudarstvennogo tekhnologicheskogo universiteta. [Bulletin of Moscow State Technological University]. - 2011. - Iss. 2. - S. 1-7 (In Russian)

13. Mukhametshin R.M. Islamovedeniye v Tatarstane [Islamic Studies in Tatarstan] Ars Islamica: $v$ chest Stanislava Mikhaylovicha Prozorova [Ars Islamica: in Honor of Stanislav Mikhailovich Prozorova] / sost. i otv. red. M.B. Piotrovskiy, A.K. Alikberov; In-t vostokovedeniya RAN. - Moscow: Nauka - Vost. lit., 2016. - S. 96-104 (In Russian)

14. Nurulla-Khodzhayeva N.T. Obshchina v musulmanskoy traditsii Tsentralnoy Azii. [Community in the Muslim Tradition of Central Asia] Vestnik MGUKI. [Bulletin of Moscow State University of Culture and Arts]. - 2012. - № 4 (48) iyul-avgust. - S. 67-71 (In Russian)

15. Nyubi G. Kratkaya entsiklopediya islama [A Concise Encyclopedia of Islam]; [per. s angl.]. - Moscow: FAIR PRESS, 2007. - 384 s. (In Russian)

16. Piotrovskiy M.B. O nekotorykh printsipakh prepodavaniya istorii i kultury islama $\mathrm{V}$ Rossii. [On Some Principles of Teaching History and Culture of Islam in Russia] Ars Islamica: $v$ chest Stanislava Mikhaylovicha Prozorova [Ars Islamica: in honor of Stanislav 
Mikhailovich Prozorov] / sost. i otv. red. M.B. Piotrovskiy, A.K. Alikberov; In-t vostokovedeniya RAN. - Moscow. Nauka - Vost. lit., 2016. - S. 43-50 (In Russian)

17. Sadur V. Tyurki. tatary. musulmane (stati. ocherki. esse) [Turks, Tatars, Muslims (articles, essays)]; [sost. i otv. red. I.Z. Mukhamedzhanov]. - Moscow: Izd. dom Marzhdani, 2012. $-400 \mathrm{~s}$.

18. Khalidov A.B. Ulama. [The Ulama] Islam. Entsiklopedicheskiy slovar. [Islam. Encyclopedic dictionary] - Moscow: Nauka. Glavnaya redaktsiya vostochnoy literatury, 1991. - S. 239-240 (In Russian)

19. Khodzhson M. Istoriya islama: Islamskaya tsivilizatsiya ot rozhdeniya do nashikh dney [The History of Islam: Islamic Civilization from the Origins to the Present]; [per. s angl. A.N. Gordiyenko, I.V. Matveyeva, N.V. Shevchenko, pod nauch. red. T.K. Ibragima]. Moscow: Eksmo, 2013. - 1088 s. (In Russian)

20. Yakupov V. Islam v Tatarstane v 1990-e gody [Islam in Tatarstan in the 1990s]. Kazan: Iman, 2005. - 144 s. (In Russian) 